\title{
Sex-Determining Region Y Protein
}

National Cancer Institute

\section{Source}

National Cancer Institute. Sex-Determining Region Y Protein. NCI Thesaurus. Code C75529.

Sex-determining region Y protein (204 aa, $\sim 24 \mathrm{kDa}$ ) is encoded by the human SRY gene.

This protein is involved in sex determination and transcriptional regulation. 